\title{
90 LET PROFESORJA IVANA GAMSA
}

5. julija 2013 je prof. dr. Ivan Gams, redni član SAZU, obhajal devetdeset let izjemno plodnega življenja. Na Oddelek za geografijo Filozofske fakultete Univerze v Ljubljani je prišel decembra 1966 kot izredni profesor in ga leta 1993 kot redni profesor z upokojitvijo zapustil. $\mathrm{V}$ šestindvajsetih letih je po njegovi zaslugi naš oddelek postal središče mednarodnega krasoslovnega vrenja in delovanja. Začelo se je leta 1965 z zelo odmevnim 4. mednarodnim speleološkim kongresom pod njegovim programskim vodstvom, izvedbeno pa je bil v rokah od-

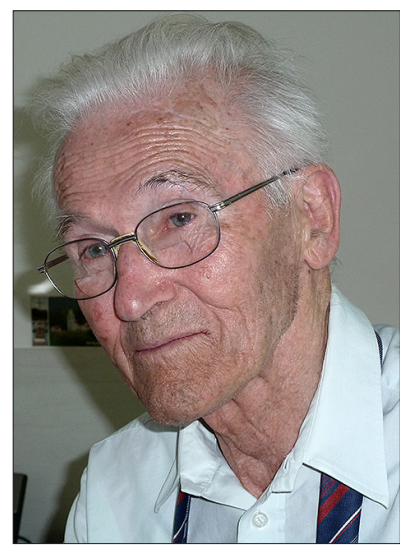
delka. Za mednarodno promocijo našega krasa in znanja si je prof. Gams prizadeval tudi z ustanovitvijo Mednarodne speleološke zveze (1965), v naslednjih dveh desetletjih pa zlasti z organizacijo mednarodnih simpozijev o kraški denudaciji (1975) in o človekovem vplivu na kras (1987). Tudi z vodenjem komisije za človekov vpliv na kras v okviru Mednarodne geografske unije je odločilno vplival na mednarodno uveljavitev slovenskega krasoslovja.

$\mathrm{Na}$ oddelku smo se ob prof. Gamsu tako kalili tudi njegovi sodelavci in bili deležni njegovega velikega znanja in širine, npr. pri nastajanju Slovenske kraške terminologije, ki je izšla korak pred podobnimi terminologijami mnogih drugih kraških dežel v Evropi, in pri kateri je imel vodilno vlogo (1973). Naj ponovimo že nekoč izrečeno, »... da so izjemne osebnosti ena največjih prednosti za stroko v nacionalnih okvirih, ker doma dajejo dragocen zgled, v tujini pa odmevajo. Tako mesto ima v slovenski geografiji prav I. Gams, ne samo zaradi izjemno obsežne bibliografije (več kot 1100 enot), temveč tudi zaradi širokih pogledov in zanimanja za najraznovrstnejše probleme v geografiji, s čimer je pogosto presenečal. Med njegove najbolj izstopajoče lastnosti kot znanstvenika, raziskovalca in pedagoga štejemo nekonformizem, pronicljivost, originalnost in mnogovrstnost geografske misli, utiranje novih raziskovalnih poti in prijemov ter odkrivanje problemov, ki se jih pred njim navadno še nihče ni dotaknil. Odlikujeta ga tudi sposobnost komuniciranja, saj je že zelo zgodaj znal svoje znanje in dognanja sproti ponujati v domačih in zlasti mednarodni znanstveni areni.«(Bibliografija akademika Ivana Gamsa, 2005, str. 5).

$\mathrm{Na}$ tem skopem prostoru lahko v nadaljevanju opisa življenja in dela prof. Gamsa naredimo le izbor nekaterih najpomembnejših dosežkov in mejnikov. Jubilant je svojo prvo študijo o pokrajini okoli Slovenj Gradca objavil leta 1951. V Društvu za raziskovanje jam Slovenije in kot član Inštituta za raziskovanje krasa v Postojni (1962-1966) se je nato razvil v vodilnega raziskovalca jam in krasa pri nas in med drugim vodil raziskovanja Triglavskega brezna. Med prvimi pri nas se je lotil kvantitativnega preučevanja kraške denudacije. Vse Gamsovo življenje sta bila zato preoblikovanje apnenčastega površja in nastajanje jam zaradi raztapljanja apnenca osrednja izziva njegovega znanstvenega 
poslanstva, $\mathrm{v}$ tem okviru tudi odlaganje sige $\mathrm{v}$ jamah, oblikovanje kraškega skalnega površja pod talno odejo, kraška polja, slepe doline itd. Njegove razprave o krasu zato sodijo med najpogosteje citirane v svetovni krasoslovni literaturi. Pustil je pomemben pečat v limnologiji slovenskih visokogorskih jezer in pri preučevanju snežnih plazov, bil je eden začetnikov geomorfološkega kartiranja, raziskovanja mikroklimatologije kraških depresij in pokrajinske ekologije, veliko je doprinesel h klimatogeografski členitvi, $\mathrm{k}$ regionalni geografiji in k vprašanjem geografske regionalizacije Slovenije ter $\mathrm{h}$ geomorfologiji posameznih slovenskih pokrajin. Gamsova raziskovalna širina se kaže tudi v odnosu do pojava intenzivnejših naravnih procesov v obliki naravnih nesreč, kjer je z organizacijo znanstvenih sestankov in kot soustanovitelj specializirane revije Ujma dobesedno oral ledino. V zrelih letih pa se je rad vračal v naročje geografije v obliki holistične povezanosti fizične in družbene komponente.

Na oddelku je začetnik predavanj iz geografije krasa in pokrajinske ekologije, ki ju je na izviren način obogatil z metodologijo in lastnimi spoznanji. Tako je doma in v tujini močno razširil krog raziskovalcev zlasti na področju krasoslovja. Opozoriti je treba tudi na Gamsovo zanimanje za šolsko geografijo. Najbolj odmeven je bil na tem področju njegov srednješolski učbenik o Sloveniji. Med vrhunce Gamsove ustvarjalnost pa zagotovo štejeta dve monografski deli o krasu, danes med najbolj branimi strokovnimi knjigami s področja krasa pri nas (1974 in 2003).

Ob osamosvojitvi Slovenije je objavil doma in zlasti v tujini lepo število člankov o geografskih 'stalnicah' Slovenije, pri čemer se mu je posrečilo o mladi državi spregovoriti na nov, svež način. Zaključujemo z ugotovitvijo, da je akademik Ivan Gams s svojim obsežnim znanstvenim in pedagoškim delom bistveno doprinesel k mednarodnemu ugledu slovenske geografije in vse slovenske znanosti, posebej še slovenskega krasoslovja.

Najpomembnejša priznanja prof. Gamsa: nagrada Sklada Borisa Kidriča za knjigo Kras (1975), častni član madžarskega in srbskega geografskega društva, častni predsednik jugoslovanskih geomorfologov, zaslužni profesor Filozofske fakultete (1993), član Evropske akademije znanosti in umetnosti, častni predsednik Zveze geografskih društev Slovenije (1996) in častni član Geomorfološkega društva Slovenije (2000), Red dela z zlatim vencem (1987), kipec civilne zaščite - najvišje priznanje civilne zaščite - za sodelovanje pri reviji Ujma (2002), posebno priznanje Blaža Kocena za življensko delo za znanstveni in pedagoški opus (DUGS, 2003), častni član ZRC SAZU (2005), plaketa z zlato značko Jamarske zveze Slovenije (2006). 